\title{
Oxidation of Pu-Bearing Solids: A Process for Pu Recovery from Rocky Flats Incinerator Ash
}

by

D. G. Karraker

Westinghouse Savannah River Company

Savannah River Site

Aiken, South Carolina 29808

\section{MASTER \\ MASTER}

This paper was prepared in connection with work done under the above contract number with the U.S. Department of Energy. By acceptance of this paper, the publisher and/or recipient acknowledges the U. S. Government's right to retain a nonexclusive, royalty-free license in and to any copyright covering this paper, along with the right to reproduce and to authorize others to reproduce all or part of the copyrighted paper. 


\section{DISCLAIMER}

This report was prepared as an account of work sponsored by an agency of the United States Government. Neither the United States Government nor any agency thereof, nor any of their employees, makes any warranty, express or implied, or assumes any legal liability or responsibility for the accuracy, completeness, or usefulness of any information, apparatus, product, or process disclosed, or represents that its use would not infringe privately owned rights. Reference herein to any specific commercial product, process, or service by trade name, trademark, manufacturer, or otherwise does not necessarily constitute or imply its endorsement, recommendation, or favoring by the United States Government or any agency thereof. The views and opinions of authors expressed herein do not necessarily state or reflect those of the United States Government or any agency thereof.

This report has been reproduced directly from the best available copy.

Available to DOE and DOE contractors from the Office of Scientific and Technical Information, P. O. Box 62, Oak Ridge, TN 37831; prices available from (423) 576-8401.

Available to the public from the National Technical Information Service, U. S. Department of Commerce, 5285 Port Royal Road, Springfield, VA 22161. 


\section{DISCLAIMER}

Portions of this document may be illegible electronic image products. Images are produced from the best available original document. 
Keywords: $\mathrm{Pu}(\mathrm{VI})$ Ternary Oxides, $\mathrm{PuO}_{2}$ Dissiolving, Peroxide oxidation of $\mathrm{PuO}_{2}$, Treatment of $\mathrm{PuO}_{2}-$ Bearing Residues

$$
\text { WSRC-TR-97-023i }
$$

Oxidation of Pu-Bearing Solids: A Process for Pu Recovery from Rocky Flats Incinerator Ash

D. G. Karraker

Chemical, and Hydrogen Technology section

Savannah River.Technology Center

Aiken, SC 29808

18 July 1997

Summary

High-fired $\mathrm{PuO}_{2}$, RFP ash heels, and synthetic RFP incinerator ash were easily soluble after oxidation of $\mathrm{Pu}$ (IV) to $\mathrm{Pu}$ (VI) by heating with $\mathrm{Na}_{2} \mathrm{O}_{2}$ or $\mathrm{KO}_{2}$ to $450^{\circ}$ for two hours. This offers a route to the recovery of $\mathrm{Pu}$ from these and similar $\mathrm{PuO}_{2}$-bearing solids that can be carried out in present equipment. Evidence for new compounds $\mathrm{K}_{2} \mathrm{PuO}_{4}, \mathrm{~K}_{4} \mathrm{PuO}_{5}$ and $\mathrm{K}_{6} \mathrm{PuO}_{6}$ is presented. A process for recovery of $\mathrm{Pu}$ from RFP incinerator ash is presented.

\section{Introduction}

Several DOE sites have Pu-bearing powders or residues that, under current regulations, must have the $\mathrm{Pu}$ recovered and/or immobilized to allow disposal of the remaining material as waste. Examples are;glovebox sweepings at SRS and incinerator ash and ash heels at RFP. In general, these solids contain $\mathrm{Pu}$ at substantial levels ( $>5$ wt. \% : too high to meet the limits for WIPP storage. Pu is usually present in these solids as "high-fired" $\mathrm{PuO}_{2}$. "High-fired". $\mathrm{PuO}_{2}$ dissolves slowly and with difficulty in $\mathrm{HNO}_{3}-\mathrm{HF}$ solutions. One successful aqueous process' for dissolving $\mathrm{Pu}$ from such solids depends on oxidation of $\mathrm{Pu}\left(\right.$ IV) in the difficultly-soluble $\mathrm{PuO}_{2}$ to the $\mathrm{Pu}(\mathrm{VI})$ by oxidation with Ag(II). As this process operates by electrolytically re-oxidizing Ag(I) to Ag(II), the equipment for its operation is rather complex. A simpler method is the object of this study.

Keller and co-workers ${ }^{2,3}$ report preparing ternary oxides of $\mathrm{Np}, \mathrm{Pu}$, and $\mathrm{Am}$ with $\mathrm{Li}$ and $\mathrm{Na}$ by reacting actinide dioxides with $\mathrm{Li}_{2} \mathrm{O}$ and $\mathrm{Na}_{2} \mathrm{O}_{2}$ in a oxygen atmosphere at 400-900. The products were AC(V) and $\mathrm{AC}$ (VI) compounds such as $\mathrm{Li}_{6} \mathrm{PuO}_{6}$ and $\mathrm{Na}_{4} \mathrm{PuO}_{5}$. Yamashita, et.al., report preparing $\mathrm{Li}_{4} \mathrm{PuO}_{5}$ and $\mathrm{Li}_{3} \mathrm{PuO}_{4}$ by reacting Iiol with $\mathrm{PuO}_{2}$ at $900^{\circ}$ in an oxygen, atmosphere; the resulting products dissolved easily in $1 \mathrm{M} \mathrm{HNO}_{3}$. This work explores these and similar reactions on $\mathrm{PuO}_{2}$, RFP ash heels and synthetic RFP incinerator ash. 


\section{Experimental Methods}

Reactions were performed on a. gram scale in a muffle furnace enclosed in a glovebox. $\mathrm{Li}_{2} \mathrm{CO}_{3}, \mathrm{Li} . \mathrm{H}$, and $\mathrm{Na}_{2} \mathrm{O}_{2}$ were reagent grade; $\mathrm{KO}_{2}$ (Alfa Chemicals, Inc.) was technical grade, >95\% pure. Two types of $\mathrm{PuO}_{2}$ were used, a material fired at $900^{\circ}$ and material prepared fired at $450^{\circ}$. A synthetic incinerator ash simulating RFP ash was tested in some experiments; this material contained 21 different components with $\mathrm{SiO}_{2}(42 \%)$, carbon (19\%), $\mathrm{Fe}_{2} \mathrm{O}_{3}(5.6 \%)$ and $\mathrm{MgCO}_{3}(4.5 \%)$ as major materials in the mixture. High-fired $\mathrm{PuO}_{2}$ was added to this mixture for testing. A sample of actual RFP asin heels was also tested.

Weighed amounts of the materials tested mixed with the oxidizing agent were heated in a muffle furnace for 2 to 4 hours at temperatures from 275 to $900^{\circ}$. The products were normally $x$-rayed to determine if the $\mathrm{PuO}_{2}$ had reacted. This amounts to a "yes-no" test for a reaction. If there was no reaction, the $\mathrm{PuO}_{2}$ lines will be strong, and the x-ray will show little else. When there is a complete reaction, the $\mathrm{PuO}_{2}$ lines will not be seen. New lines usually appear which may or may not be found in the $x$-ray catalog.

Dissolution of the reaction products under mild conditions $\left(\mathrm{HNO}_{3}, \mathrm{RT}, \mathrm{I}^{-2} \mathrm{hrs}\right)$ provided a semi-quantitative measure of the success of the oxidation. It was assumed that $\mathrm{PuO}_{3}$ would only dissolve under strenuous conditions ( $8 \mathrm{M} \mathrm{HNO}_{3}, 80-100^{6}, 4-8$ hours) and therefore any $\mathrm{Pu}$ dissolved was Pu(VI). This assumption appears to be sound; spectra of the solutions identified only $\mathrm{Pu}(\mathrm{VI})$.

Resúlts

Three different treatments were investigated for high-fired $\mathrm{PuO}_{2}^{\prime}$, low-fired $\mathrm{PuO}_{2}$, RFP "ash heels" and a synthetic incinerator ash mixed with high-fired $\mathrm{PuO}_{2}$. An initial experiment reacted highfired $\mathrm{PuO}_{2}$ with a $25 \%$ mole excess of $\mathrm{Na}_{2} \mathrm{O}_{2}$, calculated by assuming the reaction was

$$
\mathrm{PuO}_{2}+2 \mathrm{Na}_{2} \mathrm{O}_{2}-\cdots-\longrightarrow \mathrm{Na}_{4} \mathrm{PuO}_{5}+1 / 2 \mathrm{O}_{2}
$$

The mixture was heated at $450^{\circ}$ for 5 hours. The $x$-ray powder pattern of the black product was similar to that of $\mathrm{Ca}_{2} \mathrm{PuO}_{5}$; no $\mathrm{PuO}_{2}$ lines were present. The product dissolved in $8 \mathrm{M} \mathrm{HNO}_{3}$ in $1 / 2$ hour and $88 \%$ of the theoretical $\mathrm{Pu}$ present was recovered.

Rather than react the synthetic ash heels directly--which would involve oxidizing both the $\mathrm{PuO}_{2}$ and 18 wt. $\%$ carbon content of the synthetic ash with $\mathrm{Na}_{2} \mathrm{O}_{2}$--the synthetic incinerator ash was heated overnight at $700^{\circ}$ to burn out the carbon (weight loss, 17\%) then reacted with $\mathrm{Na}_{2} \mathrm{O}_{2}$. Based on the amount of $\mathrm{PuO}_{2}$ present, $\mathrm{Na}_{2} \mathrm{O}_{2}$ was $300 \%$ in excess. $\mathrm{PuO}_{2}$ was detected by $\mathrm{x}$-ray in the fired sample. This experiment was repeated with 500\% excess $\mathrm{Na}_{2} \mathrm{O}_{2}$; no $\mathrm{PuO}_{2}$ I ines were found in the $x$-ray pattern of the product. The large excess 
of $\mathrm{Na}_{2} \mathrm{O}_{2}$ required was due to competing reactions with other components of the synthetic ash, particularly $\mathrm{SiO}_{2}$.

A sample of RFP ash heels was also reacted at $450^{\circ}$ for 7 hours with $\mathrm{Na}_{2} \mathrm{O}_{2}$ in a weight ratio of $1 \mathrm{~g}$ ash heels to $1.16 \mathrm{~g} \mathrm{Na}_{2} \mathrm{O}_{2}$. The product was a brown cake that showed a few $\mathrm{PuO}_{2}$ lines in its x-ray. Recovery of Pu by dissolving was 8.9 wt. $\%$ of the sample. From earlier work, this sample of ash heels is about 10 wt.\% Pu:

Athough Yamashita, :et. ai. ${ }^{4}$ were able to prepare Pu(VI) compounds by reacting $\mathrm{LiOH}$ or $\mathrm{Li}_{2} \mathrm{CO}_{3}$ in $100 \%$ oxygen atmosphere, attempts to reproduce this result on synthetic ash heels or $\mathrm{PuO}_{2}$ (heating at $900^{\circ}$ for 4 hours) failed. The $x$-ray patterns for both showed strong $\mathrm{PuO}_{2}$ lines and dissolving in $8 \mathrm{M} \mathrm{HNO}_{3}$ recovered only $5 \%$ of the $\mathrm{Pu}$ present. The failure of this approach is attributed to firing in air instead of $100 \%$ oxygen.

Potassium superoxide, $\mathrm{KO}_{2}$, has more oxygen on a weight basis than $\mathrm{Na}_{2} \mathrm{O}_{2}, 45$ wt. $\%$ vs 41 wt. $\%$, but decomposes above $300^{\circ}$ to a mixture of $\mathrm{K}_{2} \mathrm{O}_{2}$ and $\mathrm{KO}_{2}$. Tests with $\mathrm{KO}_{2}$ as an oxidizing agent were run on low-fired $\mathrm{PuO}_{2}$ over the temperature range $275^{\circ}$ to $450^{\circ}$. X-ray powder patterns of the products identified three patterns; $\mathrm{PuO}_{2}, \mathrm{a}$ pattern isostructual with potassium uranium oxide $\left(\mathrm{K}_{2} \mathrm{UO}_{4}\right)$. and a pattern isostructual with plutonium oxide sulfide, $\mathrm{Pu}_{2} \mathrm{O}_{2} \mathrm{~S}$. The $\mathrm{K}_{2} \mathrm{UO}_{4}$ pattern is assumed to be that of $\mathrm{K}_{2} \mathrm{PuO}_{4}$, the identity of the compound represented by the $\mathrm{Pu}_{2} \mathrm{O}_{2} \mathrm{~S}$ pattern has not been established. Qualitative results of the reaction between $\mathrm{PuO}_{2}$ and $\mathrm{KO}_{2}$ are shown in Table 1.

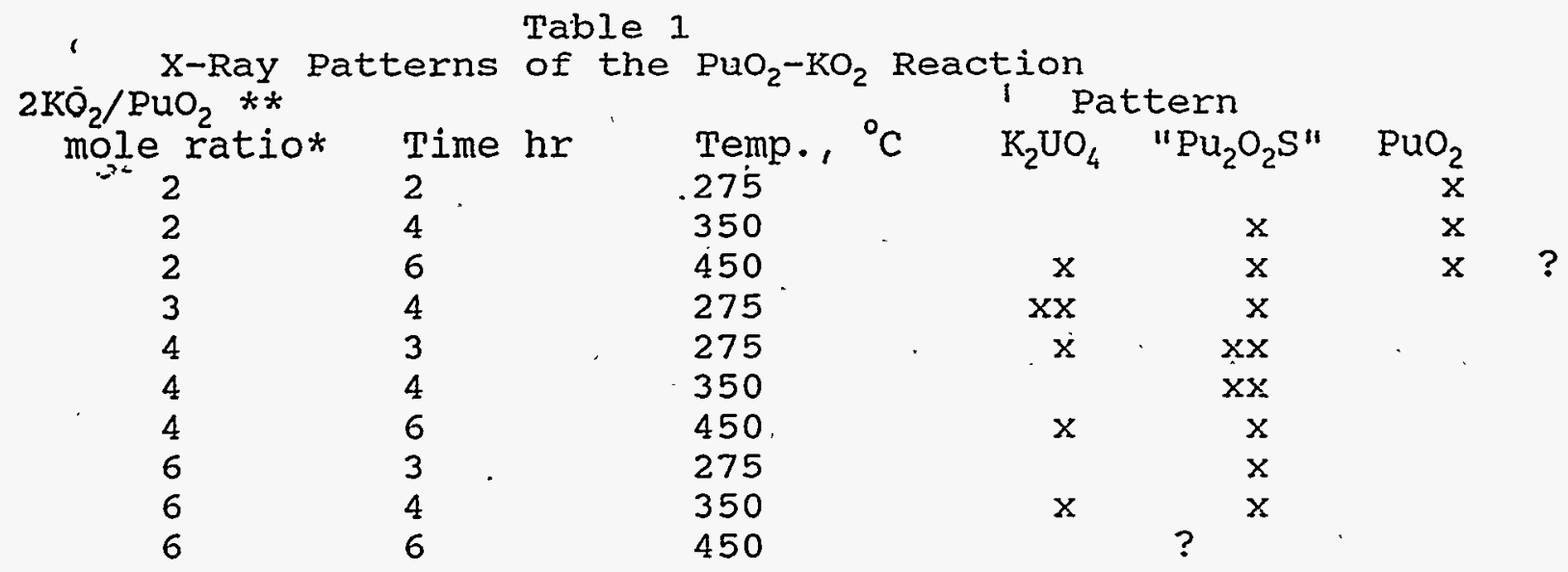

* Calculated for $\mathrm{KO}_{2} 6 \mathrm{PuO}_{2}=1$

** $\mathrm{PuO}_{2}$ fired at $450^{\circ}$

The lines of the $\mathrm{x}$-ray patterns of $\mathrm{K}_{2} \mathrm{PuO}_{4}$ and " $\mathrm{Pu}_{2} \mathrm{O}_{2} \mathrm{~S}$ " are listed in Table 2. Figures 1 ard 2 show the powder patterns of $\mathrm{K}_{2} \mathrm{FuO}_{4}$ and

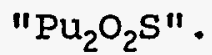




\section{Table 2}

Lines and Intensities for $\mathrm{K}_{2} \mathrm{PuO}_{4}$ and " $\mathrm{Pu}_{2} \mathrm{O}_{2} \mathrm{~S}$ "

\begin{tabular}{cc}
\multicolumn{2}{c}{$" \mathrm{Pu}_{2} \mathrm{O}_{2} \mathrm{~S} "$} \\
$\mathrm{~d} . \AA^{\mathrm{I}}$ & $\mathrm{I}$ (rel.) \\
6.75 & 20 \\
6.08 & 7 \\
4.28 & 5 \\
3.49 & 1 \\
3.38 & 9 \\
3.03 & 10 \\
2.25 & 2 \\
2.13 & 3 \\
1.98 & 1 \\
1.97 & 2 \\
1.88 & 1 \\
1.74 & 2 \\
1.56 & 1 \\
1.51 & 1 \\
1.42 & 1
\end{tabular}

$\begin{array}{crcr} & & \\ \mathrm{K}_{2} \mathrm{PuO}_{4} & & \\ \mathrm{~A} & \mathrm{ReI} & \mathrm{I} & \text { (\%) } \\ 6.43 & 40 & \\ 6.05 & 48 & \\ 4.25 & 72 & \\ 3.45 & 40 & \\ 3.12 & 25 & \\ 3.01 & 100 & \\ 2.67 & 18 & \\ 2.29 & 20 & \\ 2.13 & 42 & \\ 2.01 & 24 & \\ 1.91 & 34 & \\ 1.74 & 46 & \\ 1.51 & 17 & \\ 1.46 & 15 & \\ 1.42 & 24 & \end{array}$

The products of the $4 / 1$ and the $6 / 1$ reactions dissolved completely in $1 \mathrm{M} \mathrm{HNO}$ at room temperature. There was a small residue of $\mathrm{PuO}_{2}$ when the $3 / 1$ product dissolved; the $2 / 1$ product dissolved to leave $\mathrm{PuO}_{2}$, as expected from the $\mathrm{x}$-ray data.

The; reaction between $\mathrm{KO}_{2}$ and high-fired. $\mathrm{Pu}_{2}$ was investigated at a $4 / 12 \mathrm{KO}_{2} / \mathrm{PuO}_{2}$ ratio at $350^{\circ}$ and $400^{\circ}$. No $\mathrm{PuO}_{2}$ was detected in the $\mathrm{x}-$ ray patterns of he products; $73 \%$ of the $\mathrm{Pu}$ in the the $400^{\circ}$ product dissolved in $1 \mathrm{M} \mathrm{HNO}_{3}$ to yield a $\mathrm{Pu}(\mathrm{VI})$ solution. About $5 \%$ of the sample did not dissolve, possibly because of insufficient acid.

RFP ash heels and $\mathrm{KO}_{2}$ were reacted for 4 hours at $275^{\circ}$ in a weight ratio of $0.5 \mathrm{~g} \mathrm{KO}_{2}$ per $\mathrm{g}$ ash heels. The product cake showed a strong $\mathrm{PuO}_{2}$ pattern on $\mathrm{x}$-ray and two other patterns identified as silicates; dissolving in $1 \mathrm{M} \mathrm{HNO}$ recovered only $1-2 \%$ of the pu but did dissolve 35\% of the sample. Evidently a more $\mathrm{KO}_{2}$ is necessary to accommodate the reaction of $\mathrm{SiO}_{2}$ with $\mathrm{KO}_{2}$. The low yield of $\mathrm{Pu}$ from the dissolving suggests that the $\mathrm{PuO}_{2}$ in RFP ash heels is coated with $\mathrm{SiO}_{2}$. (Ash heels are the residue from repeated leaching of incinerator ash with hot $8 \mathrm{M} \mathrm{HNO}_{3}-0.2 \mathrm{M} \mathrm{HF.)}$

$\mathrm{PuO}_{2}$ and $\mathrm{KO}_{2}$ were reacted with each in stiochoimetric excess to determine the $\mathrm{K} / \mathrm{Pu}$ (mole) ratio of products of the $\mathrm{PuO}_{2}-\mathrm{KO}_{2}$ reaction. The product of the reaction with excess $\mathrm{PuO}_{2}$ at $275^{2}$ was leached'with $0.25 \mathrm{M} \mathrm{HNO}_{3}$ and the excess $\mathrm{PuO}_{2}$ filtered, dried and weighed. From the initial reactant weights and the weight of the excess $\mathrm{PuO}_{2}$, the $\mathrm{K} / \mathrm{Pu}$ ratio of the product was found to be 2.0 , 
suggesting that the product was $\mathrm{K}_{2} \mathrm{PuO}_{4}$. A second experiment reacted $\mathrm{KO}_{2}$ with excess $\mathrm{PuO}_{2}$ at $450^{\circ}$; the $\mathrm{K} / \mathrm{Pu}$ ratio was found to be 2.7 . $\mathrm{A}$ mixture of $\mathrm{K}_{2} \mathrm{PuO}_{4}$ and $\mathrm{K}_{4} \mathrm{PuO}_{5}$ is a possible explanation.

Excess $\mathrm{KO}_{2}$ reacted with $\mathrm{PuO}_{2}$ at $400^{\circ}$ was leached with water, and the potassium in the leach water determined by acid-base titration. $\left(\mathrm{KO}_{2}, \mathrm{~K}_{2} \mathrm{O}_{2}\right.$, and $\mathrm{K}_{2} \mathrm{O}$ all decompose to $\mathrm{KOH}$ in water). From the initial weight's and the excess potassium determination the $\mathrm{K} / \mathrm{Pu}$ ratio was calculated to be 5.9 . This suggests that the red-brown product of the reaction was $\mathrm{K}_{6} \mathrm{PuO}_{6}$.

\section{Application to Processing Rocky Flats Incinerator Ash}

Rocky Flats Plant (RFP) incinerator ash has the nominal composition 18 wt. $\%$ graphite, 40 wt. $\% \mathrm{SiO}_{2}, 5$ wt. $\% \mathrm{Fe}_{2} \mathrm{O}_{3,} 3$ wt. $\% \mathrm{Al}_{2} \mathrm{O}_{3}, 5$ wt. $\mathrm{PuO}_{2}$ and minor amounts of about 20 other oxides. Several of these oxides react with $\mathrm{Na}_{2} \mathrm{O}_{2}$ and thus increase the amount of $\mathrm{Na}_{2} \mathrm{O}_{2}$ required to oxidize $\mathrm{PuO}_{2}$. Three of the major components were reacted with $\mathrm{Na}_{2} \mathrm{O}_{2}$ to determine the amount of $\mathrm{Na}_{2} \mathrm{O}_{2}$ they would require.

The reaction with powdered graphite was tested by heating a $\mathrm{Na}_{2} \mathrm{O}_{2}-$ graphite mixture to $450^{\circ}$ for 2 hours; $\mathrm{Na}_{2} \mathrm{O}_{2}$ was $30 \%$ excess for the reaction

$$
\mathrm{C}+2 \mathrm{Na}_{2} \mathrm{O}_{2} \rightarrow \mathrm{CO}_{2}+2 \mathrm{Na}_{2} \mathrm{O}-\cdots \mathrm{Na}_{2} \mathrm{CO}_{3}+\mathrm{Na}_{2} \mathrm{O}
$$

The product dissolved in acid with the evolution of $\mathrm{CO}_{2}$ and left no. residue.

The, reaction between $\mathrm{SiO}_{2}$ and $\mathrm{Na}_{2} \mathrm{O}_{2}$ is assumed to be

$\mathrm{Na}_{2} \mathrm{O}_{2}+\mathrm{SiO}_{2}-\rightarrow \mathrm{Na}_{2} \mathrm{SiO}_{3}+1 / 2 \mathrm{O}_{2}$

Two experimental tests found that $66 \%$ of the $\mathrm{SiO}_{2}$ reacted when the ratio of reactants was $1 / 1$, and $89 \%$ of the $\mathrm{SiO}_{2}$ reacted when the ratio was $1.36 \mathrm{Na}_{2} \mathrm{O}_{2} / \mathrm{SiO}_{2}$. Both experiments calculate that $150 \%$ of the stoichiometric amount of $\mathrm{Na}_{2} \mathrm{O}_{2}$. is necessary to consume all the $\mathrm{SiO}_{2}$.

$A$ test of the reaction between $\mathrm{Na}_{2} \mathrm{O}_{2}$ and $\mathrm{Fe}_{2} \mathrm{O}_{3}$. found a barely detectable reaction at $450^{\circ}$ for 2 hours. An estimated $95 \%$ of the $\mathrm{Fe}_{2} \mathrm{O}_{3}$ did not react.

A processing scheme for recovery of $\mathrm{Pu}$ from $\mathrm{RFP}$ incinerator ash involves the following steps:

1. Seiving the ash to -50 mesh.

2. Roastung the ash at $700^{\circ}$ for several hours to oxidize graphite. This method of disposing of graphite is chosen over oxidation because of the large amount $\mathrm{Na}_{2} \mathrm{O}_{2}$ required, $13 \mathrm{~g}$ per $\mathrm{g}$ graphite.

3. The graphite-free ash is mixed with an equal weight $\mathrm{Na}_{2} \mathrm{O}_{2}$. 
4 The mixture is heated to $450^{\circ}$ for two hours. In this work it was found that a food can is a satisfactory container. Should this and the preceeding steps be performed at RFP, after oxidation the can could be capped and shipped to Savannah River for aqueous processing.

5. The treated ash is charged to a dissolver and dissolved, can and all, in $8 \mathrm{M} \mathrm{HNO}_{3}$.

6. After dissolving, 10 vol. $\% 1$ wt. $\%$ gelatin is added to the solution to coagulate silica, and the solution filtered.

7. The $\mathrm{Pu}(\mathrm{VI})$ solution is reduced to $\mathrm{Pu}(\mathrm{IV})$ with $\mathrm{NaNO}_{2}$ and $\mathrm{Pu}$ recovered by anion exchange.

\section{Discussion}

Oxidation of residues containing $\mathrm{PuO}_{2}$ by heating with either $\mathrm{Na}_{2} \mathrm{O}_{2}$ or $\mathrm{KO}_{2}$ is a low-temperature treatment that could be easily adapted as a pre-treatment to dissolving $\mathrm{PuO}_{2}$-bearing material. present equipment would be sufficient for the oxidation; a dissolver that could be flushed would be required, since some

components of the residues would probably be insoluble and their accumulation could lead to interference with succeeding processing.

The reaction of $\mathrm{PuO}_{2}$ with $\mathrm{Na}_{2} \mathrm{O}_{2}$ is an adaptation of an analytical method for treatment of difficultly-soluble solids. If a large excess of $\mathrm{Na}_{2} \mathrm{O}_{2}$ is used essentially everything vill be converted to water-soluble salts. Potassium superoxide, $\mathrm{KO}_{2}$, was used as a substitute for $\mathrm{K}_{2} \mathrm{O}_{2}$, which reacts violently with $\mathrm{O}_{2}$ to form $\mathrm{KO}_{2}$. About $300^{\circ}, \mathrm{KO}_{2}$ begins to decompose td $\mathrm{KO}_{2}, \mathrm{~K}_{2} \mathrm{O}_{2}$ and $\mathrm{O}_{2}$. The reaction reverses on cooling. Either $\mathrm{Na}_{2} \mathrm{O}_{2}$ or $\mathrm{KO}_{2}$ will oxidize $\mathrm{PuO}_{2}$ satišfactorily and allow an easy dissolving of the $\mathrm{Pu}(\mathrm{VI})$ ternary oxide.

The two compounds produced by heating $\mathrm{KO}_{2}$ with $\mathrm{PuO}_{2}$ were not found in a literature search, although the analogous compounds for the other alkali metals have been reported. The reactions with excess $\mathrm{PuO}_{2}$ do allow a separation of unreacted material, but the x-ray patterns of the $\mathrm{Pu}(\mathrm{VI})$ were swamped by the strong $\mathrm{PuO}_{2}$ Iines. The qualitative evidence suggests that $\mathrm{K}_{2} \mathrm{PuO}_{4}$ and $\mathrm{K}_{4} \mathrm{PuO}_{5}$ are the two compounds formed.

The reaction of $\mathrm{PuO}_{2}$ with excess $\mathrm{KO}_{2}$ indicated that the residue after water leaching was $\mathrm{K}_{6} \mathrm{PuO}_{6}$, however it is not certain that this was the original compound, since the ternary oxide may have reacted with the water leach.

Acknowledgements: The author is indebted to Alice Murray for calling his attention to the Pu(VI) ternary oxides, and to Beverly. Wall for experimental assistance. 


\section{References}

1. I. A. Bray and J. I. Ryan, "Catalyzed Electrolytic Dissolution of Plutonium Dioxide", Radioactive Waste Management, 6, 127 (1982).

2. C. Keller, I. Koch and K. H. Walter, J.Inorg. Nucl. Chem.,27, $1205(1965)$.

3. C. Keller, L. Koch, and K. H. Walter, J. Inorg.Nucl. Chem., 27, 1225 (1965).

4. T. Yamashitá, K. Ohuchi, K. Takahashi and T. Fujino in "Transuranium Elements" ed. I. R. Morss and J. Fuger. American Chemical Society, Washington, DC 1992 p441 et seq.

5. C. A. Kraus and E. F. Whyte, J. Am. Chem. Soc.,48, 1781, (1926). 6. D. M. Yost and H. Russell, Jr., "Systematic Inorganic Chemistry," Prentice-Hall, Inc. N.Y. (I946) p 386. 